\title{
EDUCATION FOR SUSTAINABLE DEVELOPMENT IN THE EFL CLASSROOM: EXPLORING INTERSUBJECTIVITY
}

\author{
Jackson Ver Steeg Jr. \\ Wenzao Ursuline University of Languages, 900 Mintsu $1^{\text {st }}$ Road, Kaohsiung 807, Taiwan R.O.C.
}

\begin{abstract}
English as foreign language (EFL) curricula commonly include certain sustainable development (SD) topics, which are covered in a limited fashion within a larger topic base. Because SD is a global issue and participation in that conversation occurs primarily in the English language, students in the EFL classroom are in a prime position to benefit from an increased exposure to an SD lexicon and SD topics. While traditional education for sustainable development (ESD) focuses on student awareness of issues and behaviors, psychology practitioners suggest that additional gains in student attitudes may be achieved by focusing on the ontology of humans and their relationships to Nature. Accordingly, this study examines ways of introducing inner work and intersubjectivity into the EFL classroom with the goal of examining and altering the viewpoint of students such that they see themselves more of Nature rather than apart from it. Examples of classroom modifications are given, including content and text recommendations, as well as course structure. Justifications are presented for including mindfulness and intersubjectivity in exercises in the EFL classroom as a method to practice ESD.
\end{abstract}

\section{KEYWORDS}

Intersubjectivity, Education for Sustainable Development, ESD, EFL, SD

\section{INTRODUCTION}

The October 2018 reports from both the United Nations' Intergovernmental Panel on Climate Change and the World Wildlife Federation (WWF) contain dire warnings of the need to protect our environment and pursue sustainable practices, and suggest that time is of the essence. The former reports that we may have a little as 12 years to cut industrial emissions by $45 \%$, while the latter presents studies that show a wildlife population loss of on average $60 \%$ over the last 40 years. Further, WWF UK Chief Executive Tanya Steele notes that "we are the first generation to know we are destroying our planet and the last one that can do anything about it" (Picheta, 2018). That report also quoted researchers who estimate that, by 2050, there may be more plastic in the ocean than fish.

If these reports are credible, something is very, very wrong. Education for sustainable development (ESD) is an attempt to empower today's students with abilities and responsibility for creating a sustainable future, not only in terms of these critical issues of environmental degradation and climate change, but also economic and social issues such as poverty and gender inequality. Although there is no one specific definition for ESD, a well-considered one would be expressed similarly to this definition from UNESCO Bangkok:

Education for Sustainable Development (ESD) is a learning process (or approach to teaching) based on the ideals and principles that underlie sustainability and is concerned with all levels and types of learning to provide quality education and foster sustainable human development - learning to know, learning to be, learning to live together, learning to do and learning to transform oneself and society. (UNESCO, Definition of ESD, n.d.)

Campus initiatives at all levels have addressed the need for the introduction of sustainable development (SD) issues into curricula. One place where SD issues are generally addressed more haphazardly rather than through a dedicated ESD curriculum is in the English language classroom, which, understandably, tends to be 
primarily driven by language teaching issues and pays only passing attention to SD issues when they are part of a language curriculum in the form of a chapter or two of an English textbook.

The global conversation about SD issues, however, is a continuing dialog that is guided not only by scientific research but also by language, with its communicative potential and transformative ability. This conversation, though, seems to be governed by a few major languages_-English, French, and Spanish. The former two by virtue of intergovernmental organizations such as the U.N., and the latter by virtue of the fact that many countries of concern for sustainability are in Central and South America. For students whose native language is other than those, they may be fortunate enough to encounter SD ideas in great detail in their native language and develop complex opinions and inspired ideas. In order to express those ideas on a global stage, however, an ability to do so in one of the languages governing the conversation would be instrumental, and could have a profound effect on the ability to improve sustainability. The better we develop SD concepts, vocabulary, and ways of relating to other actors, the better equipped non-native English speakers will be to participate in global solutions.

\section{THEORETICAL BACKGROUND}

In the university English as a foreign language (EFL) classroom here in Asia, we may teach our students about our oceans, about recycling and energy choices, or about Fair Trade coffee. We may even actually affect student behavior in terms of sustainable choices. But is it enough? These recent reports suggest that much more is required-addressing not only actions, but addressing what we generally conceptualize as "ways of thinking." Current trends in ESD do indeed measure student attitudes towards sustainable development, in terms of their awareness of issues and their attitudes about such things as being a citizen of the world, feeling a responsibility to help those who need it, knowing their behavior can impact people in other countries, boycotting companies who have unsustainable practices, and having respect for people from other cultures. (OECD, 2018) These are all outward facing attempts to change the future, and as such are necessary for the type of change that is required.

A point I have argued in other places is that sustainable development (SD) is a topic that should not only be in every EFL classroom, but should be a stand-alone topic of English study. Our students are studying English, among other reasons, as a means to participate globally. Because SD is a global issue which requires global solutions, developing both an understanding of sustainable development topics and the ability to use an English lexicon (see Appendix A) which permeates discussion of those topics allows students to inject their voices into the argument and help define the future.

But for our students - attached to their cellphones, facing a barrage of advertising with every waking hour-are these outward-facing postures of attitudinal and behavioral change, when combined with an English lexicon of SD, sufficient for the enactment of change? Recent research suggests that students in Asia are well-informed about SD issues and expressed a great deal of concern about them (Wee, Ariffin, Ng \& Shabudin, 2017). While some researchers (Caniglia et al., 2018) promote such ideas as a digital transnational collaboration for sustainability, this paper pursues a lateral methodology. A method of engagement with SD by ecopsychologists has addressed the issue of the degradation of the natural environment by using ideas of inner crisis that are traditionally used therapeutically with individuals, and has extended those ideas toward the crisis affecting our natural environment. Work by Cohen, Bai, and Rabi has outlined an argument for sustainability education not as one requiring changes in behavior such as energy-saving, but instead as one where the change for sustainability must be driven by nothing less than a radical change in our collective ontology such that we "disrupt the damaging habit of perceiving Earth....as a resource base for creating material wealth....and human[s] as 'tools'...to provide the labour for producing consumer goods" (Cohen, Bai, \& Rabi, 2014, p. 24). Drawing from the psychology that is generally applied to individuals, Cohen et al. draw a thread starting with what they recognize as self-destructive behavior in society in general, which results in addictions meant to guard against psychological pain. To them, consumerism can be understood by Kaza (as cited in Cohen, 2014, p. 24) as such an addiction meant to fill a lack in our collective society, and an indicator of what they read as an attachment rupture in our collective psyche, as has been explained by Jordon (cited in Cohen, 2014, p. 25). Following the research on psychological therapy with regards to healing the wounds of such an attachment rupture, Cohen et al. propose to create 
relational environments in which afflicted individuals can experience intersubjectivity: that is, that is, the experience of both being heard, seen, listened to, received, and being energetically "held." Within such environments, opportunity to experience what has been profoundly lacking... will be possible. Warm and nurturing relational experience in a secure, safe, and trust-building relationship begins to re-build the missing ontological security and soothe humans who are experiencing existential anxiety. (2014, p. 25)

They propose building this environment in classrooms to affect healing in students and guide changes in sustainability from an ontological perspective, and provide a few vignettes to exemplify how this would work in practice. While instructive, the vignettes seem somewhat out of place in an EFL classroom as they rely on concepts of meditation, healing and sharing rather than language instruction, and may not be embraced by students as within the realm of activities that develop English language ability. Nevertheless, I suggest that the work of ESD which addresses attitudinal rather than behavioral changes can find a home in the EFL classroom as well.

What might be the goal of such a shift in the focus of ESD in the EFL class? It might argued that I suggest this is a only a political endeavor, linguistically arming students for social critiques or political action. Hodgson, Vlieghe, and Zamojski (2018) have argued that education carrying that as its goal, namely critical pedagogy, is ineffective, as the forms of knowledge produced by such an endeavor are under constant threat of undermining by anti-intellectualism, rendering the transformative silent. They suggest, instead an Arendtian positioning that emphasizes a "love for the world" that conceptualizes education for its own sake and which "is not about debunking the evil of the world, but about care and attention to the good inherent to that world (cf. Latour)" (2018, p. 15). In the realm of the EFL classroom, therefore, while a primary benefit may arise from engagement in the language of SD issues, a secondary benefit is this taking care of the good of the world.

Accordingly, a method to introduce the concept of intersubjectivity and its potential benefits into the EFL classroom is needed. This paper suggests ways to do that, as well as to promote the restoration of an "intrinsic value" to Nature, valuing it not for its utility, but for its existential right to exist (Bai, 2009, p. 95). Below, some suggestions for the EFL classroom are presented, with justifications from within these ecopyschological models.

\section{CLASSROOM STRATEGIES}

This section presents a number of areas where sustainability concepts can be integrated into the EFL classroom in a manner that, unlike standard scattershot coverage of SD issues in many current English textbooks, takes as a focus the acknowledgement of both Nature and education as existing for themselves. In other words, Nature presented not as valued by its utility or political positioning. This is by no means a comprehensive list, but merely suggestions of how to proceed.

\subsection{Content}

\subsubsection{Texts}

In order to promote understanding of intersubjectivity in students and address the rupture in our collective psyche, emphasis should be placed on texts that introduce ideas of interconnectedness with people and with Nature, including those that detail failures in sustainability. It stands to reason that the texts chosen for a course can have a great effect on a student's inner belief system. Many texts can be found at different levels. These include indigenous peoples' stories, Western mythology, children's literature, and stories from graded readers.

Children's literature is rich with stories that address issues of sustainability, but ones that deal with issues of world views and promoting the voice of the marginalized are less commonly presented. Figure 1 presents a list of children's literature texts that would be appropriate for use in the EFL classroom, and which promote ontologies of inclusiveness. In terms of texts that have the potential to successfully present in the EFL classroom a radical shift in ontological beliefs, many of these texts make the strongest and most enduring statements by addressing complicated issues in an uncomplicated language that EFL students can easily 
relate to. Even texts not ostensibly about SD issues can be used to examine intersubjectivity. In one instance, we used Lois Lowry's children's novel Number the Stars, which takes as its subject matter Denmark's WWII Jewish population, to enter into a conversation about responsibility. Students were strongly engaged with the discussion of how "the golden rule" is expressed in Judaism, Christianity, Islam and Hinduism. When I then asked if that concept was limited to humans or could be extended include Nature, subsequent group conversations elicited that a number of students, though clearly challenged by the ontological suggestion, began to see it as a useful, if not illuminating conceptualization of responsibility.

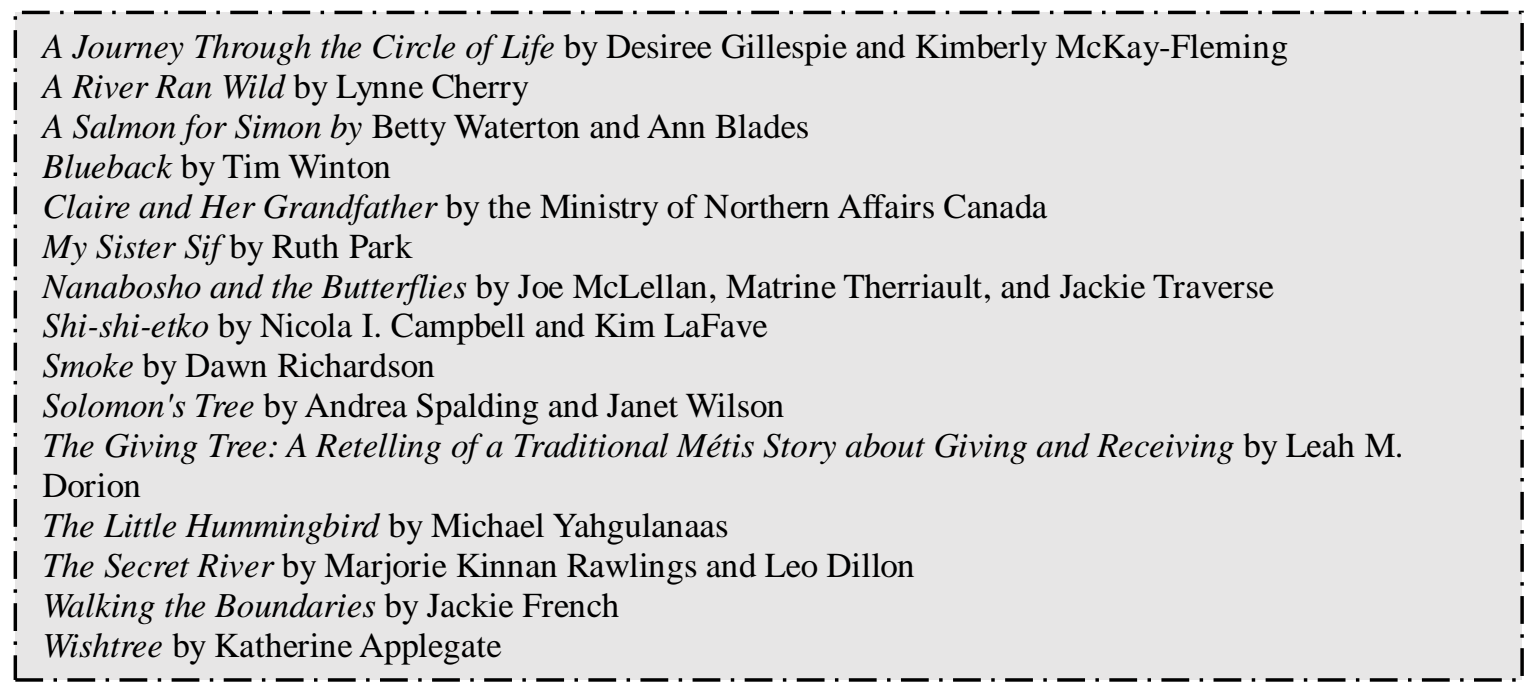

Figure 1. Selected Texts from Children's Literature Featuring Alternative Ontologies

Another kind of text commonly used in the EFL classroom are graded readers, which are used most successfully in Extensive Reading (ER) programs. Texts are either abridged versions of classics or original stories, and are scaled in difficulty to meet the levels of both very low and very high level English learners. Notable in regards to introducing SD issues are Cambridge English Readers (scaled from 1 to 6), which are original stories and often address contemporary issues. Titles such as Blood Diamonds (level 1), Within High Fences (level 2), Deadly Harvest (level 6), and Rabbit-Proof Fence (Oxford Bookworms level 3) contain themes of development, migration, and biodiversity, and social justice. While these adequately fulfill needs to address SD themes, most do not deal with alternative worldviews except as a sub-theme. Certain texts, however, can function to give a voice to those who have suffered, which is a means to develop intersubjectivity. Rabbit-Proof Fence addresses the family separation of Australian aboriginals, while Jojo's Story (Cambridge level 2) details the tale of a child in a war-torn country. While there are currently not a great number of titles that perform such a function, certain graded readers are short enough and accessible enough to enable a class discussion that would allow an approach to intersubjectivity. In my college ER classroom, these two texts were instrumental in starting a discussion about marginalization and "othering"both in the text and in how these ideas could be located in local history, notably the history of colonialist/aboriginal relationships in Taiwan.

Another textual locale for discovering and discussing ways of thinking about the world around us is found in English language poetry and poetic prose, though its use may be limited to upper level students. Poetry can be used as a major or supplemental text, and serve as a springboard for exploring issues of worldviews and of imagining our world of the future. Poets such as Robert Frost have, in numerous poems, concerned themselves with humans and the meaning that "places experienced" give to their lives. Robert Browning explores the connection between landscape and emotion in his two poems "Meeting at Night" and "Parting at Morning," suggesting the ability of Nature to be an actor in a dialogue involving personal emotion. Alfred, Lord Tennyson's "The Eagle" provides a beautiful short vignette for students as an example of imaging the world from something else's point of view. Students at upper levels can access Ralph Waldo Emerson's "Self-Reliance," which serves as a primer into self-reflection and ontological change. Henry David Thoreau's Walden may also serve a similar function. Interestingly, a few children's literature texts have developed transcendentalist thought, and would appeal to lower level students. The delightful Henry Hikes to Fitchburg and Henry Builds a Cabin by D.B. Johnson can easily serve as an introduction to transcendentalist concerns for even low level English language students. 


\subsubsection{Designed Learning Units}

In addition to reconsidering texts only, instructors may want to take advantage of various pre-designed teaching units. There are a number of free web-based resource sites that address SD issues in general, but the pool of resources which address the healing work necessary for our collective psyche is comparatively shallow. This paper presents a sampling of designed learning units that may be adapted for use in the EFL classroom. The group Learning for a Sustainable Future collects classroom plans to cover many different SD issues, from climate change to global inequalities, on a website called Resources for Rethinking (http://resources4rethinking.ca/en/home). While it is a wide-ranging and valuable resource, the appropriate exercises here are those that address the development of alternative worldviews, and bring intersubjectivity to the forefront. Table 1 presents a list of learning units that address the development of alternative subjectivities, and which may be appropriate for use in the EFL classroom. University-aged learners at lower English levels may find some of the exercises targeted at native-speaking elementary students to be conceptually too simple, so instructors should take care to choose a learning unit that is compatible with both English level and conceptual ability.

Table 1. Learning units that potentially aid in developing a different human ontology, from Resources for Rethinking (http://resources4rethinking.ca/en/home). URLs have been provided for content from other providers

\begin{tabular}{|c|c|c|}
\hline $\begin{array}{c}\text { Student } \\
\text { Level }\end{array}$ & Learning Unit Title & Summary \\
\hline \multirow[t]{3}{*}{ Elementary } & $\begin{array}{l}\text { Maq and the Spirit of the } \\
\text { Woods }\end{array}$ & $\begin{array}{l}\text { Video from National Film Board of Canada exploring } \\
\text { interrelationships between natural, human, and spiritual worlds. } \\
\text { (http://www.nfb.ca/film/maq_spirit_woods/) }\end{array}$ \\
\hline & First Nations Games & Unit introduces outdoor games played by First Nations children \\
\hline & $\begin{array}{l}\text { Walking with the Earth- } \\
\text { Pimohtiwin }\end{array}$ & $\begin{array}{l}\text { Introduces First Nations ideologies of interconnectedness and ties } \\
\text { them to a Nature walk }\end{array}$ \\
\hline \multirow[t]{3}{*}{$\begin{array}{l}\text { Elementary, } \\
\text { Middle }\end{array}$} & $\begin{array}{l}\text { Creating a Three Sisters } \\
\text { Garden }\end{array}$ & $\begin{array}{l}\text { Teaches about interdependence and interconnectedness in plants } \\
\text { and humans }\end{array}$ \\
\hline & $\begin{array}{l}\text { Creation and Unity of Earth, } \\
\text { The White Buffalo Calf } \\
\text { Woman and the Sacred Pipe }\end{array}$ & $\begin{array}{l}\text { Uses aboriginal legends presented in the book as a base for learning } \\
\text { activities taken from: Keepers of the Earth: Native American } \\
\text { Stories and Environmental Activities for Children }\end{array}$ \\
\hline & The Woolastoqewiyik & Explores the interdependency of humans and the Earth \\
\hline $\begin{array}{l}\text { Middle, } \\
\text { Secondary }\end{array}$ & $\begin{array}{l}\text { Inuit Observations on Climate } \\
\text { Change }\end{array}$ & $\begin{array}{l}\text { Video presents climate change from a different, more immediate } \\
\text { perspective }\end{array}$ \\
\hline \multirow[t]{5}{*}{ Secondary } & Towards A New Perspective & $\begin{array}{l}\text { Tied to David Suzuki's movie Force of Nature addressing the } \\
\text { stewardship of the Earth }\end{array}$ \\
\hline & Four Directions Teaching & $\begin{array}{l}\text { Video presents knowledge and philosophy from a First Nations } \\
\text { perspective }\end{array}$ \\
\hline & $\begin{array}{l}\text { Journey into New Worlds } \\
\text { The Matrix of Life }\end{array}$ & $\begin{array}{l}\text { Tied to David Suzuki's television series The Sacred Balance } \\
\text { addressing the interconnectedness of life and spiritual world views }\end{array}$ \\
\hline & $\begin{array}{l}\text { Tread Lightly: Learning From } \\
\text { the Past, Defining Our Future }\end{array}$ & $\begin{array}{l}\text { Exploring the decline and failure of previous civilizations } \\
\text { (http://resources.tiged.org/tread-lightly-learning-from-the-past- } \\
\text { defining-our-future) }\end{array}$ \\
\hline & Yukon Kings & $\begin{array}{l}\text { Video from Global Oneness Project detailing traditional ecological } \\
\text { knowledge in salmon fishing } \\
\text { (https://www.globalonenessproject.org/library/films/yukon-kings) }\end{array}$ \\
\hline $\begin{array}{l}\text { Elementary, } \\
\text { Middle, } \\
\text { Secondary }\end{array}$ & $\begin{array}{l}\text { Cultivating Peace in the 21st } \\
\text { Century }\end{array}$ & $\begin{array}{l}\text { Module from Cultivating Peace.ca that promotes a culture of peace } \\
\text { and understanding of others' values } \\
\text { (http://www.cultivatingpeace.ca/main.html) }\end{array}$ \\
\hline
\end{tabular}

\subsection{Warm-up Exercises}

An easy method to build community or mindfulness is to use a warm-up exercise in the first 5-10 minutes of class through a group discussion intended to re-establish bonds between students. As noted above, in certain classroom situations, these exercises may seem appropriate by setting the tone for further learning. In the EFL classroom, however these exercises should be tied to increasing language learning and usage in order to be embraced by students. Guiding questions in an opening group discussion can be both simple and effective: 
How are things going this week? How was last weekend? What are you most worried about this week? What is your biggest challenge this week? Alternatively, opening exercises could focus on a mindfulness exercise. While many mindfulness exercises such as breathing exercises seem well out of the purview of the EFL classroom, ones that use writing can incorporate English language practice. A simple one to use is a reflective writing where students are asked to write in as much detail as possible for ten minutes on a series of simple questions, as "Be quiet and focus on the place around you. What do you hear? What do you see? What do you taste? What do you smell? and What do you feel?" After such a writing exercise, students may be better centered to engage with SD class work. A number of studies have found positive effects of mindfulness exercises, particularly in students aged 15-18 (Carsley, Khoury \& Heath, 2018). As this is the age range for high school/university EFL classes, this suggests that students may derive benefits from such exercises. Use in my college-level EFL classes has been positive. While many are at first either confused at the inclusion of such an exercise or amused as its novelty value or seeming simplicity, observation suggests that many students quickly come to enjoy the exercise, especially as a matter of routine that establishes a calming and supportive learning environment. I also believe that this exercise served to strengthen the teacher-student rapport, perhaps located in the shared sense of the vulnerability felt by performing a new routine or new experience. End-of semester evaluations confirm many of these observations, such as "I love how we start our class. So calm" and "interesting way to start English, but I heard things I never heard before."

\subsection{Group Work}

The most effective classroom format to foment change in the collective psyche of society is to work collectively and use group work as an organizing structure. Much of a student's time in university is spent in performing tasks in isolation-taking tests, doing individual homework and completing writing assignments. These can be isolating and competitive, rather than seeking a collective interconnectedness. By utilizing group projects, group writing, and group homework, students can be immersed in the type of problem-solving necessary for sustainable development, as well as developing empathy and understanding, seeing their roles in larger projects, and forming a supportive inner learning community that encourages healing. Group activities can vary widely in their goals, processes, and outcomes, so not all group activities may be suitable for development of intersubjectivity and collective thinking, but likely successful formats would be group writing, group projects, and group discussion. Again, there is broad latitude as to what may be successful, so instructors should design group work such that other elements identified here can be incorporated into the EFL classroom.

\subsection{Examination of Ideologies}

One obvious area of exploration and criticism that can be used in the EFL classroom is modern materialistic life and consumption behaviors. Writing assignments, especially, can be useful in exploring the isolating effects of materialism and consumption, described by some as "an internalization of self-limiting and destructive patterns" (Illich, 2000). As a counter to the insidious effects of the overwhelming influence of consumerism, students could be asked to consider the life cycle of a product of technology or produce, or analyze their own consumption practices and the emotions that accompany those practices. Another exercise encouraging reflection on the role of material worth may also to be a "no electricity/energy day" where students are asked to go without any energy-driven products for a period of time and write a reflective essay on the experience, focusing on the emotions and connections that they felt during the experiment. An alternative to this assignment may be a "no news" or "no social media week" to help students realign with more immediate and sensory experiences. Like group work, there is a great number of possible projects that can address inner work and help heal the "rupture" previously identified. Developing a successful project entails giving adequate discussion time before and after the project to situate the criticism of what is, for most students, a well-engrained process of materialism. 


\subsection{Writing Assignments Incorporating Positive Peer Review}

For better alignment with developing the ESD mode of intersubjectivity which allows voices of suffering to be heard, writing assignments in the EFL classroom should include an element of peer-review that includes both positive and negative feedback. In order to counter the sometimes negative effects of traditional educational experiences that prioritize correction and conformation to writing conventions, writing assignments can be structured with a peer-review element where reviewers are asked to make both constructive critical comments as well as specifically positive comments. These take the form of complimenting writing ideas and descriptions. As simple as this is, students are generally accustomed to negative critical responses to their personal writing, and viewing positive responses to their own personal revelations may have encouraging and sometimes surprising effects. This type of exercise is an example of a therapeutic action that can validate their personal concerns and support the development of their inner life. Indeed, much anecdotal evidence from my writing classes suggests that students are genuinely pleased with positive feedback, and find that it supports not only their writing but also their development of positive opinions of their academic community.

\subsection{Positive Feedback}

Including positive feedback mechanisms in classes, both L1 and EFL, can greatly affect healing work and influence how students view themselves and how they relate to and act in the world. I can recall one exercise from my own primary school experience. We were instructed to write our names on the top of a piece of paper. The papers were then redistributed and circulated around the classroom, and we were asked to write one compliment for each fellow student when we received their paper. At the end of the exercise, the paper was returned to us with some 20 -odd compliments. It was a monumental feeling to hold in my hand a catalog of positive feedback about myself, and it opened up a new universe of how I related to my world. This exercise remains a testament to the significance of breaking, even temporarily, from the traditional educational environment. A similar group exercise is described by Lougheed and Coholic (2018) called Handprints, where participants trace their handprint on a piece of paper then affix the paper to their own back. Participants then take turns writing positive affirmations on each other's sheets of paper for about 15 minutes, allowing participants to share what they appreciated about others in the group while developing self-esteem and reflection $(2018$, p. 6). Interestingly, the Lougheed \& Coholic study was not performed on a group of students, but instead with youth exiting foster care. An interview with a participant points out the fact this type of positive support is, not surprisingly, rarely provided in schools, either in L1 or L2 classrooms, saying "It was nice to have other people to talk to about that kind of stuff because you know at school you don't just like talk about it with anyone" (2018, p. 7). This suggests that there is indeed a needed space for such positive feedback mechanisms, in either L1 or in EFL classrooms.

\subsection{Point of View Exercises}

Instructors should consider the inclusion of point-of-view exercises where students are asked to assume the position of one who is suffering. At the heart of this task is the development in students of what has been identified by some ecopsychologists as the need to break the culture-Nature, subject-object dichotomy which undergirds a dualistic consciousness in favor of experiencing an intersubjectivity which is "a sense of knowing the other as a 'fellow being' whose identity and welfare are bound up in some ways with one's own" (Bai, 2009, p. 99). Instead of just talking about a migrant crisis, for example, instructors could develop exercises which ask students to imagine themselves in the situation and relate the emotions that they would feel in such a situation. This could take numerous forms, and is especially useful in writing exercises. Students could also address global inequalities from a different point of view, as in a writing assignment like "A Day in the Life of Robin Hood/The Good Samaritan: 2019." Drawing a point of view exercise toward Nature can be constructed as a group activity where student groups discuss and create an Animal/Ocean/Forest/or Desert Bill of Rights. In this exercise, students should consider what rights should be given to the ocean and what rights we as citizens should share with the ocean. Other writing and discussion exercises can directed to identifying exactly how a "fellow being"- whether it be human or Nature- has an identity bound with one's own. 


\section{CONCLUSION}

The EFL classroom has been a location where certain SD topics are covered in a limited fashion within a larger topic base. Sustainable development is a global issue and participation in that conversation primarily occurs in the English language. Students in the EFL classroom are in a prime position to benefit from an increased exposure to an SD lexicon and SD topics. While traditional education for sustainable development focuses on student awareness of issues and behaviors, psychology practitioners suggest that additional gains in student attitudes may be achieved by focusing on the ontology of humans and their relationships to Nature. Accordingly, this study examines ways of introducing inner work and intersubjectivity into the EFL classroom. What can be achieved may be tremendously dependent on the dynamics of each classroom, but following these suggested exercises has had the effect in some classrooms of developing the concept in students of a - at least for the moment - shared consciousness aligned toward understanding the world around them in significantly different terms.

\section{REFERENCES}

Applegate, K. (2017). Wishtree. Feiwel \& Friends.

Bai, H., \& Scutt, G. (2009). Touching the Earth with the Heart of Enlightened Mind: The Buddhist Practice of Mindfulness for Environmental Education. Canadian Journal of Environmental Education, 14(1), 92-106.

Campbell, N. \& LaFave, K. (2005) Shi-shi-etko. Groundwood Books.

Caniglia, G., John, B., Bellina, L., Lang, D. J., Wiek, A., Cohmer, S., \& Laubichler, M. D. (2018). The glocal curriculum: A model for transnational collaboration in higher education for sustainable development. Journal of Cleaner Production, 171, 368-376.

Carsley, D., Khoury, B., \& Heath, N. L. (2018). Effectiveness of Mindfulness Interventions for Mental Health in Schools: a Comprehensive Meta-analysis. Mindfulness, 9(3), 693-707.

Cherry, L. (2002). A River Ran Wild. HMH Books for Young Readers.

Cohen, A., Bai, H., \& Rabi, S. (2014). Relationship as Teacher of Sustainability: Post-Individualist Education. Sustainable Well-being: Concepts, Issues, and Educational Practices, 23-36.

Dorion, L. (2009). The Giving Tree: A Retelling of a Traditional Métis Story about Giving and Receiving. Gabriel Dumont Institute.

French, J. (2016) Walking the Boundaries. Harper Collins.

Garimara, D.P. (2007) Rabbit-Proof Fence. Oxford University Press.

Gillespie, D. \& McKay-Fleming, K. (2015). A Journey Through the Circle of Life. Pemmican Publications.

Hancock, P. (2005). Within High Fences. Cambridge University Press.

Hodgson, N., Vlieghe, J., \& Zamojski, P. (2018). Education and the Love for the World: articulating a post-critical educational philosophy. Foro de Educación, 16(24), 7-20.

Illich, I. (2000). Deschooling society. Marion Boyars.

Intergovernmental Panel on Climate Change (IPCC). (2018, October 8). Special Report on Global Warming of $1.5{ }^{\circ} \mathrm{C}$ (SR15). Retrieved from http://www.ipcc.ch/report/sr15/

Johnson, D.B. (2000). Henry Hikes to Fitchburg. HMH Books for Young Readers.

Johnson, D.B. (2002). Henry Builds a Cabin. HMH Books for Young Readers.

Kagawa, F. (2007). Dissonance in students' perceptions of sustainable development and sustainability: Implications for curriculum change. International journal of sustainability in higher education, 8(3), 317-338.

Lougheed, S. C., \& Coholic, D. A. (2018). Arts-Based Mindfulness Group Work with Youth Aging Out of Foster Care. Social Work with Groups, 41(1-2), 165-178.

Lowry, Lois. (2011). Number the Stars. HMH Books for Young Readers.

MacAndrew, R. (2005). Blood Diamonds. Cambridge University Press.

McLellan, J., Therriault, M. \& Traverse, J. (2015). Nanabosho and the Butterflies. Pemmican Publications.

Ministry of Northern Affairs (2000). Claire and Her Grandfather. Indian and Northern Affairs Canada.

Organisation for Economic Co-operation and Development (OECD). (2018). Preparing our youth for an inclusive and sustainable world: the OECD PISA global competence framework. Retrieved November 7, 2018 from https://www.oecd.org/pisa/aboutpisa/Global-competency-for-an-inclusive-world.pdf 
Park, R. (1997). My Sister Sif. Puffin.

Picheta, R. (2018, October 30). This is the 'last generation' that can save nature, WWF says. CNN. Retrieved from https://edition.cnn.com/2018/10/29/health/wwf-wildlife-population-report-intl/index.html

Rawlings, M.K. (2011). The Secret River. Atheneum Books for Young Readers.

Richardson, D. (1985). Smoke. Penumbra Press.

Spalding, A. \& Wilson, J. (2005). Solomon's Tree. Orca Book Publishers.

UNESCO Bangkok. (n.d.) Definition of ESD. Retrieved on November 17, 2018, from http://www.unescobkk.org/education/ esd-unit/definition-of-esd/

Walker, C. (1999) Deadly Harvest. Cambridge University Press.

Waterton, B \& Blades, A. (1998). A Salmon for Simon. Groundwood Books.

Wee, M. I., Ariffin, F. N., Ng, T. F., \& Shabudin, A. F. A. (2017). Awareness and Attitudes Towards Sustainable Development Amongst Higher Education Students in Penang, Malaysia. In Handbook of Theory and Practice of Sustainable Development in Higher Education (pp. 49-64). Springer, Cham.

Winton, T. (1998). Blueback. Scribner.

World Wildlife Federation (WWF). (2018, October 22). The Living Planet Report: 2018 Aiming Higher. Grooten, M. and Almond, R.E.A. (Eds). WWF, Gland, Switzerland.

Yahgulanaas, M. \& Maathai, W., (2010) The Little Hummingbird. Greystone Books.

\section{APPENDIX A: A SUSTAINABLE DEVELOPMENT LEXICON FOR EFL STUDENTS}

A preliminary English lexicon appropriate for EFL classrooms can be drawn from a coding keyword list from Kogawa (2007), and is reproduced in part here. Additional terms from the author are added in italics.

\begin{tabular}{|c|c|}
\hline Categories & Examples \\
\hline \multicolumn{2}{|l|}{ Aspects } \\
\hline Environmental & $\begin{array}{l}\text { alternative/clean energy; biodiversity; conservation; } \\
\text { environment/environmental; environmental/ecofriendly; earth; green; organic } \\
\text { food; permaculture; recycle; }\end{array}$ \\
\hline Social & $\begin{array}{l}\text { corruption; diversity; equality; equity; public transport; people; quality of life } \\
\text { society; social; social justice; }\end{array}$ \\
\hline Economic & economy; fair trade; poverty; production \\
\hline \multicolumn{2}{|c|}{ Temporal (including time projection and rhythm) } \\
\hline The future & future; future generations; future needs; our children; tomorrow \\
\hline Long-term & constant; continuation; long-term; overtime; on-going \\
\hline Improvement & advancement; betterment; growth; improvement; progress \\
\hline Stability & consistent; stable; stay the same \\
\hline \multicolumn{2}{|c|}{ Approaches towards sustainable development/sustainability } \\
\hline Governance, policy, politics & $\begin{array}{l}\text { Agenda 21; Brundtland report; government; sustainable development goals } \\
(\text { SDGs); UN; EU; } 17 \text { SDGs, } 2030 \text { Agenda for Sustainable Development }\end{array}$ \\
\hline Learning and action & action; awareness; consideration; education; empowerment; research \\
\hline Management & control; maintain; manage; plan; prevent; support \\
\hline $\begin{array}{l}\text { Technology, building, and } \\
\text { design }\end{array}$ & alternative technology; eco-design technology \\
\hline Homeostasis & balance; cycle; harmony; self-sufficiency \\
\hline Human attitude & $\begin{array}{l}\text { accountability; altruism; commitment ethical; health; moral; responsibility; } \\
\text { well-being }\end{array}$ \\
\hline \multicolumn{2}{|r|}{ (2) C } \\
\hline Local & community; local \\
\hline Global/international & global; worldwide \\
\hline \multicolumn{2}{|c|}{ Perceptions of sustainable development/sustainability } \\
\hline Perceptions/feelings & $\begin{array}{l}\text { beneficial; challenging; controversial; essential; good; needed; necessary; } \\
\text { positive }\end{array}$ \\
\hline
\end{tabular}

